\title{
ПРОФІЛАКТИЧНА РОБОТА СЕРЕД НАСЕЛЕННЯ - ПОТРЕБА ЧИ НЕОБХІДНІСТЬ ДЛЯ СУЧАСНОЇ ЛЮДИНИ
}

\author{
К. В. Жавріченко \\ Костянтинівський медичний коледж \\ тернопільський національний медичний університет \\ імені І. Я. Горбачевського МОЗ Украӥни
}

У статті проаналізовано необхідність проведення медичними сестрами профілактичної роботи серед населення.

\section{PREVENTIVE WORK IN THE POPULATION - THE NEED OR NECESSITY FOR THE MODERN PEOPLE}

\author{
K. V. Zhavrichenko \\ Kostantyniv Medical College \\ I. Horbachevsky Ternopil National Medical University
}

The article analyzes the need for preventive work by a nurse among people.

Вступ. Повсякденне життя людини регламентовано сукупністю норм і правил: морально-етичних, правових тощо. Саме завдячуючи цим правилам і нормам суспільство перебуває увідносній стабільності. Знання правових норм дає змогу людині досить комфортно почуватися у непростому сучасному світі: знаючи «правила гри», менше шансів потрапити у неприємну ситуацію через їх порушення - адже незнання закону не звільняє від відповідальності.

Світова громадськість занепокоїна значним зростанням рівня захворюваності з домінуванням хронічної патології над гострою. Особливо це стосується країн із низькою соціальною культурою та недостатньою увагою державних органів до профілактичної медицини [1].

Ця проблема $\epsilon$ актуальною для вітчизняної системи охорони здоров'я. Серед усього населення України лише кожного п'ятого (21,9 \%) можна вважати здоровою людиною, 40,6 \% - практично здоровими, а більше третини (37,5 \%) мають хронічні захворювання. Зростає рівень психічних і невротичних розладів, патології серцево-судинної, ендокринної, травної систем та інших неепідемічних захворювань, притаманних

(с) К. В. Жавріченко, 2020 сучасній цивілізації. Як наслідок, хронічні захворювання не тільки переважають, але і знижують тривалість життя, підвищують інвалідність і смертність, призводять до негативних економічних наслідків для сімей, держави і суспільства загалом [4, 5].

Однією з найважливіших проблем інтенсифікації медичної допомоги населенню та профілактики хронічних захворювань $є$ залучення всього медичного персоналу до пропаганди здорового способу життя людини.

Нині державна програма охорони здоров'я населення передбачає підготовку не тільки сімейних лікарів, а й сімейних медичних сестер.

Основна частина. Медичні сестри $є$ важливою ланкоюу галузі охорони здоров'я, без якої неможливе формування, підтримання, збереження і відновлення здоров'я громадян України. Сучасна модель підготовки медичних сестер передбачає, що медична сестра - це фахівець з професійною освітою, який поділяє філософію сестринської справи. Має право на виконання відповідної професійної діяльності та творчо здійснює медсестринський процес.

Для вирішення питання потреби у профілактичній роботі середнім медичним персоналом проведено 
опитування серед жителів м. Харкова, щоб проаналізувати дані, зрозуміти на якому рівні знаходиться інформування щодо профілактики захворювань та встановити рівень зацікавленості самих громадян до превентивної медицини, пропаганди серед населення. Було обрано такий метод опитування, як анкетування, що, в свою чергу, допомогло чітко виявити проблеми сьогодення стосовно поширення знань про профілактичну діяльність та встановити шляхи її вирішення. Анкетування проводили шляхом опитування в системі «Інтернет» заздалегідь складеною анкетою. Одними із основних питань були: шляхи інформування пацієнтів щодо профілактики неінфекційних захворювань, тематика майбутніх бесід, можливість спілкування із медичними сестрами на тему здорового способу життя та шляхи його проведення.
Як відомо, Всесвітня організація охорони здоров'я (ВОО3) розглядає сестринський персонал як реальний потенціал для задоволення зростаючих потреб населення в доступній медичній допомозі. Саме тому значна увага Міністерства охорони здоров'я (МОЗ) України на сьогодні приділяється удосконаленню середньої ланки медичних працівників, при цьому особливий акцент ставлять на покращення роботи медичних сестер.

В анкетуванні взяли участь 200 осіб, серед них $42 \%$ чоловіків та $58 \%$ - жінок. Вік пацієнтів коливався від 20 до 65 років.

Враховуючи принцип важливості інформування пацієнтів про стан їхнього здоров'я та шляхи його покращення, вивчено джерела отримання інформації хворими (табл. 1).

\section{Таблиця 1. Джерела приймання інформації пацієнтами щодо профілактики}

неінфекційних захворювань (\%)

\begin{tabular}{|l|c|c|c|}
\hline \multicolumn{1}{|c|}{ Джерела інформації } & Усі респонденти & Чоловіки & Жінки \\
\hline Сімейний лікар & 27 & 12 & 15 \\
\hline Дільнична медична сестра & - & - & - \\
\hline Друзі & 14 & 4 & 7 \\
\hline $\begin{array}{l}\text { Медичний персонал приватних діагностичних } \\
\text { центрів }\end{array}$ & 11 & 4 & 10 \\
\hline Засоби масової інформації & 21 & 8 & 13 \\
\hline Мережа «нтернет» & 27 & 14 & \\
\hline
\end{tabular}

Отримані дані свідчать, що майже половина респондентів (48 \%) отримує інформацію щодо профілактики захворювань із засобів масової інформації та мережі «Інтернет», 14 \% - від друзів, і тільки в 38 \% випадків від медичних працівників. Від медичних сестер таку інформацію не отримав жоден із опитаних харків'ян.

За результатами анкетування виявлено, що за медичною допомогою більшість пацієнтів звертаються лише тоді, коли захворіли - 83 \%, і незначна частина - з метою профілактики захворювань (17\%).

Враховуючи важливість подолання основних факторів ризику виникнення неінфекційних захворювань у населення, медичний персонал повинен проводити активні бесіди, тематичні лекції з пропаганди здорового способу життя. Вивчено основні тематичні напрямки, які змогли би зацікавити людей з метою покращення їхнього здоров'я (табл. 2).

Враховуючи дані про вплив психічного перевантаження на розвиток захворювань, можна вважати, що 36 \% осіб хотіли б отримати інформацію про здоровий спосіб життя (профілактична спрямованість),
14 \% зацікавилися лікуванням захворювань (фізична реабілітація та фітотерапія), поведінковий та інформативний напрямки (32 \%), 8 \% опитаних зацікавилися всіма перерахованими напрямками. На жаль, 9 \% опитаних не цікавить жодна інформація про профілактику основних неінфекційних захворювань.

За допомогою результатів анкетування встановлено в якій формі громадяни хотіли 6 отримувати інформацію профілактичного характеру від медичних працівників середньої ланки. При цьому для більш правдивого і прозорого результату додали питання, які дозволять побачити чи зацікавлено населення взагалі в отриманні цих знань та готовності їх отримати саме від медичних сестер без керівництва лікаря, рівень довіри українців до середнього медичного персоналу (табл. 3).

Отримані результати вказують на готовність пацієнтів спілкуватися з медичними сестрами і отримувати від них інформацію (56 \%), 23 \% не наважуються спілкуватися з медсестрами без лікаря і 21 \% - взагалі були налаштовані скептично. 
Таблиця 2. Тематика профілактичних заходів (\%)

\begin{tabular}{|l|c|c|c|}
\hline \multicolumn{1}{|c|}{ Тематика } & Усі респонденти & Чоловіки & Жінки \\
\hline $\begin{array}{l}\text { Здоровий спосіб життя і профілактика } \\
\text { захворювань }\end{array}$ & 22 & 6 & 16 \\
\hline $\begin{array}{l}\text { Інформація про захворювання, які час- } \\
\text { то спостерігають }\end{array}$ & 23 & 5 & 3 \\
\hline $\begin{array}{l}\text { Спосіб життя з невиліковною хворобою, } \\
\text { догляд за такими хворими }\end{array}$ & 9 & 6 & 9 \\
\hline $\begin{array}{l}\text { Роль психосоматики у виникненні та } \\
\text { лікуванні хвороб }\end{array}$ & 14 & 5 & 5 \\
\hline Фізична реабілітація & 13 & 8 & - \\
\hline Ваша відповідь: & 1 & 1 & - \\
\hline Фітотерапія & 1 & 1 & \\
\hline $\begin{array}{l}\text { Кармічний вплив вчинку на подальший } \\
\text { розвиток хвороби }\end{array}$ & 9 & & \\
\hline Не цікавить жодна & 8 & 3 & 5 \\
\hline На всі наведені & & & \\
\hline
\end{tabular}

Таблиця 3. Види (можливості) отримання консультації щодо профілактики захворювань безпосередньо у медичних сестер (\%)

\begin{tabular}{|l|c|c|c|}
\hline \multicolumn{1}{|c|}{ Види } & Усі респонденти & Чоловіки & Жінки \\
\hline Індивідуальні заняття & 25 & 9 & 16 \\
\hline Групові заняття & 19 & 4 & 15 \\
\hline Інтерактивні тренінги & 12 & 6 & 6 \\
\hline Лише під керівництвом лікаря & 23 & 10 & 13 \\
\hline Вважаю це непотрібним взагалі & 21 & 13 & 8 \\
\hline
\end{tabular}

Висновки. Проведене дослідження виявило потребу в наданні інформації щодо профілактики неінфекційних захворювань медичними працівни- ками середньої ланки. Найчастіше пацієнти хочуть отримувати ії у вигляді індивідуальних або групових занять та на інтерактивних тренінгах.

\section{СПИСОК ЛІТЕРАТУРИ}

1. Ашхабадская декларация по профилактике и борьбе с неинфекционными заболеваниями в контексте положений политики Здоровье - 2020 [Электронный ресурс] // Европейская министерская конференция ВОЗ по профилактике и борьбе с неинфекционными заболеваниями в контексте положений политики Здоровье - 2020 (Ашхабад, 3-4 дек. 2013 г.). - Режим доступа : http: // www.euro.who.int/ru/media-centre/ events/2013/12/ashgabat-conference-on-nocommunicablediseases.

2. Взаємодія «держава-суспільство» заради здоров'я: зарубіжний досвід боротьби з неінфекційними захворюваннями / Н. О. Рингач, О. М. Дзюба, О. Р. Ситенко,
А. О. Керецман // Вісник соціальної гігієни та організації охорони здоров'я України. - 2015. - № 1. - С. 35-41.

3. Коваленко А. В. Медико-організаційні недоліки профілактики хвороб системи кровообігу в Україні та шляхи їх подолання / А. В. Коваленко, В.І.Клименко // Вісник соціальної гігієни та організації охорони здоров'я України. - 2014. - № 4. - С. 12-16.

4. обґрунтування сучасних освітніх програм з профілактики неінфекційних захворювань / Д. Д. Дячук, Т. С. Грузєва, Ю. С. Мазепа // Східноєвропейський журнал громадського здоров'я. - 2016. - № 1 (26). - С. 79-80.

5. Теренда Н. О. Смертність від серцево-судинних захворювань як державна проблема / Н. О. Теренда // Вісник наукових досліджень. - 2015. - № 4. - С. 11-13. 